\title{
An evidence-based relationship between technical assistance and productivity in cocoa from Tocache, Peru
}

\author{
Relación basada en evidencia entre la asistencia técnica y la \\ productividad en el cacao de Tocache, Peru \\ Angie Higuchi ${ }^{1}$ (D), Daniel Coq-Huelva ${ }^{2}$ (D) , Cristian Vasco ${ }^{3}$ (D), Rafaela Alfalla-Luque ${ }^{4}$ (D), \\ Rocío Maehara ${ }^{5}$ (D)

\begin{abstract}
1Department of Management, Universidad del Pacífico, Lima, Peru. E-mail: a.higuchi@up.edu.pe
²Department of Applied Economics II and Institute of Latin American Studies, Universidad de Sevilla, Seville, Spain. E-mail: dcoq@us.es ${ }^{3}$ Faculty of Agricultural Sciences, Universidad Central del Ecuador, Quito, Ecuador. E-mail: clvasco@uce.edu.ec ${ }^{4}$ Department of Financial Economics and Operations Management, Universidad de Sevilla, Seville, Spain. E-mail: alfalla@us.es ${ }^{5}$ Department of Engineering, Universidad del Pacífico, Lima, Peru. E-mail: rp.maeharaa@up.edu.pe
\end{abstract}

\begin{abstract}
How to cite: Higuchi, A., Coq-Huelva, D., Vasco, C., Alfalla-Luque, R., \& Maehara, R. (2023). An evidence-based relationship between technical assistance and productivity in cocoa from Tocache, Peru. Revista de Economia e Sociologia Rural, 61(1), e253614. https://doi.org/10.1590/1806-9479.2021.253614
\end{abstract}

\begin{abstract}
The growth of small-scale Peruvian farmers is highly dependent on cocoa factor productivity. Agricultural extension programs can help to improve farm productivity using available resources. Thus, the objective of this study is to estimate the productivity of Peruvian cocoa farming and identify if frequent technical assistance impacts on farmers' technical efficiency. The data came from a survey of 379 cocoa farmers in Tocache, San Martin (177 producers who sell through intermediaries and 202 who are cooperative members), conducted between January and June 2015. This article is supported by the interaction of two associated techniques: the production function and the technical efficiency technique based on stochastic frontier analysis (SFA). The key findings were that the estimated coefficients for labor, capital, land and fertilizer were positive to cocoa production. Our outcomes also show there is a (marginally) significant relationship between technical assistance and technical efficiency ( $p$-value $<10 \%)$. There is also a positive relationship between efficiency and other socioeconomic characteristics of being a male, having experience in cocoa cultivation and practicing non-diversification in other crops. Policymakers could consider these results to improve farm management systems and, therefore, the competitiveness of the cocoa plantations in the Peruvian Amazonia.
\end{abstract}

Keywords: cooperative, cocoa, production function, technical efficiency, Peru.

Resumen: El crecimiento de los pequeños agricultores depende en gran medida de la productividad del cacao. Los programas de extensión agrícola pueden ayudar a mejorar dicha productividad utilizando los recursos disponibles. Por tanto, el objetivo de este estudio es estimar la productividad del cacao peruano e identificar si la frecuencia de asistencia técnica afecta la eficiencia técnica de los agricultores. Los datos provienen de una encuesta a 379 productores de cacao en Tocache, San Martín, realizada entre enero y junio de 2015. Este artículo se sustenta en la interacción de dos técnicas: la función de producción y la eficiencia técnica basada en el análisis de frontera estocástica. Los hallazgos clave fueron que los coeficientes estimados de trabajo, capital, tierras y fertilizantes fueron positivos para la producción. Asimismo, se muestra la existencia de una relación entre la frecuencia de asistencia técnica y la eficiencia técnica ( $p$-valor $<10 \%)$. También existe una relación positiva entre la eficiencia y otras características socioeconómicas al ser hombre, tener experiencia en el cacao y no practicar la diversificación en otros cultivos. Los formuladores de políticas públicas podrían considerar estos resultados para mejorar los sistemas de manejo agrarios y, por tanto, la competitividad de los cacaoteros en la Amazonía peruana.

Palabras clave: cooperativa, cacao, función de producción, eficiencia técnica, Perú. 


\section{Introduction}

In recent years, there have been a number of transformations in the agri-food value chains. There are also growing requirements for quality, volume and timing of supply (Gibbon et al., 2010). As a consequence, an increased number of differentiated segments have been developed following those criteria (Barham \& Sylvander, 2011; Ponte, 2009). Cocoa and chocolate are no exception to this general trend, and in recent years, a rising number of cocoa marketing channels have emerged to satisfy increasingly diversified patterns of consumer demand (Cidell \& Alberts, 2006; Wollni \& Brümmer, 2012). Prices have been the most important trading element in the cocoa and chocolate commodity chain (CCCC) (Wollni \& Brümmer, 2012); however, the CCCC is becoming increasingly segmented, with distinctive quality strands emerging that are based on price (Cidell \& Alberts, 2006). Thus, international processors are currently paying higher prices to producers' organizations that are able to meet certain quality standards (Wollni \& Brümmer, 2012). Cocoa is a paradigmatic case because around $80-90 \%$ of cocoa is produced by small family farmers (World Cocoa Foundation, 2014); therefore, all the aforementioned processes have had and are still having a particularly relevant impact on small farmers.

Even though Amazonia is the largest tropical forest in the world and has a great agroecological potential, it is a relatively understudied region (Porro et al., 2015). Until the start of the 2000s, agrarian production in many areas of the Peruvian Amazonia, particularly in the province of Tocache, was marked by illegal cropping of coca leaves. Although there are high risks associated with illegal drug trafficking, in monetary terms, coca is a particularly profitable crop. In spite of this, the production of coca leaves in Tocache's province, although still present, has substantially declined and been partially displaced to other more remote areas. According to the National Commission for Development and Life Without Drugs (DEVIDA in Spanish), Peru had 54,655 hectares in 2019 under coca cultivation (Comisión Nacional para el Desarrollo y Vida sin Drogas, 2020) (see Appendix 1). However, as a consequence of the process of withdrawal and progressive relocation of coca plantations, many of the old coca farms have been transformed into cocoa farms. According to FAOSTAT (Organización de las Naciones Unidas para la Agricultura y la Alimentación, 2021), in 2019, 130,378 ha of cocoa were cultivated in Peru, with a total production of 135,928 MT of cocoa beans. Thus, the Peruvian and South American share of world production is around $3 \%$ and $23 \%$, respectively (see Appendix 2).

Cocoa farmers in developing countries, particularly smallholders, face several production and marketing constraints (Mojo et al., 2017). The majority of cocoa farms are located in rural areas that are characterised by poor infrastructure and services, which hamper access to final markets (Martin et al., 2015; Van Dun 2009). Additionally, farmers have low bargaining power in the overall CCCC (Martin et al., 2015). The different criteria and conventions that have been developed to differentiate quality are origin, flavour, organoleptic properties and chemical composition (Ponte, 2009). In some cases, new quality metrics have been a great opportunity for Amazonian cocoa producers, who have been widely exploited in countries such as Ecuador (Coq-Huelva et al., 2018). In the Peruvian case, the improvement of the drying and fermentation processes has been particularly relevant for eliminating bitterness, enhancing aroma and removing excess moisture from the beans (Laroche et al., 2012). Enhancement of the post-harvesting processes is associated with the construction of stock centres, with each stock centre having the capacity and the machinery (cocoa fermenters, solar and liquid petroleum gas dryers, and multi-certification compliant storage facilities) to comply with international buyers' standards for quality and quantity (Melo \& Hollander, 2013).

At the same time, similar to other food chains, there are increasing requirements in terms of volume, timeliness of delivery and quality (Gibbon et al., 2010), and smallholders face increasing 
difficulty in meeting such requirements. The capacity to satisfy the changing demands of industrial processors and final consumers is generating intense pressure and inequalities among producers. This pressure occurs particularly if the producers act independently, or in other words, without being integrated into broader farmer organizations (Coq-Huelva et al., 2018; Gutiérrez, 2014). Cooperatives can improve quality processes, and favour the expansion of specific marketing channels (Schweisguth, 2015). These organizations have broken the monopoly of marketing activities that were previously under the complete control of middlemen. Nevertheless, this arrangement is not by itself a guarantee of success. To be effective, cooperatives and their activities need to be coordinated with other agents in the commodity chain (Coq-Huelva et al., 2018).

In the context of increasing stress over prices because of farmers' low bargaining power, the pressure to obtain satisfactory returns is particularly high. Since resources are limited, there is a need for innovative ways of farming that allow more efficient and sustainable use of these resources (Lampach et al., 2018). Consequently, it is relevant to measure the combination of inputs that producers have to choose in order to obtain the greatest profit. A key factor that has been largely neglected by previous research is the effect of assistance programs on technical efficiency (Lampach et al., 2018). To the best of our knowledge, this is the first study to address the level of technical efficiency in any cropping system in Peru, and consequently also the first study to analyse the impact of assistance programs in farm production. In this framework, we have explored the different factors that explain the existence of systematic differences in efficiency among farms with a focus on the role of assistance programs. Thus, the objectives of this study are to first identify the different factors, and then to estimate their contribution to the increased production of cocoa farms in the Tocache province, with a focus on the role of technical assistance. In this context, this article makes two main contributions to the existing academic literature. The first contribution is linking the quantitative analysis of technical efficiency to the framework of general reflections regarding transformations in the CCCC and the conditions of production and exchange, and the second contribution is simultaneously dealing with the problem of technical efficiency and marketing through two different but related statistical and econometric techniques: the production function and the technical efficiency technique based on stochastic frontier analysis (SFA).

The remainder of this article is organized as follows. The second section provides a literature review, and the third section presents the methodology, including the survey data used in the analysis that included socioeconomic and marketing variables, among others. The fourth section presents the data and empirical model, the fifth section presents the results and discussion and the main conclusions and policy recommendations are presented in the final section.

\section{Literature review}

Cocoa world production is facing increasingly demanding challenges because it is closely dependent on farmland expansion and the non-depletion of new arable land (Besseah \& Kim, 2014). However, if there is low production efficiency, output could be increased without requiring additional conventional inputs and new technology (Kyei et al., 2011). Therefore, in view of the low cocoa agrarian prices and the existing pressure to rise monetary income (particularly considering the always existing possibility of cropping highly profitable coca leaves), farmers' efficiency is a particularly relevant issue, and carrying out empirical measurement of efficiency and technical progress would be a rational strategy for improving the performance of agrarian management systems and, therefore, escalating profitability (Kyei et al., 2011). Agrarian efficiency has remained an important subject of empirical investigation, particularly in developing economies where the majority of farmers lack financial resources (Danso- 
Abbeam et al., 2012) and the output of individual farmers largely depends on various inputs as well as other specific issues (Kyei et al., 2011). Total efficiency is an ideal situation that can be only achieved by a relatively small portion of farmers, which means that the majority of farms will have some degree of technical inefficiency. However, knowing that farms are technically inefficient is irrelevant unless the sources of the inefficiency are adequately identified and corrected (Admassie \& Matambalya, 2014).

Adoption of new technology is an effective way to tackle low productivity in agriculture. Technical assistance programs (in particular technical assistance and agricultural extension programs) generate transfers of knowledge and provide training about new technologies (Torres \& Davalos, 2019). Extension programs have been introduced worldwide with the objective of upgrading human capital by diffusing production methods, input use and management practices (Lampach et al., 2018). Such extension programs are often associated with public subsidies that aim only to improve technical efficiency, but also to increase production and support farmers' incomes. In the framework of extension programs, there are often training actions that are particularly designed to enhance the technical efficiency of farmers (To-The \& Nguyen-Anh, 2020). Nonetheless, deficiencies in extension services are also widely reported, especially in developing countries (Lampach et al., 2018). One of the reasons for these deficiencies is that access to technology and technical services by smallholders and cooperatives is often constrained by lack of government support for the implementation of technology in rural areas (Gutiérrez, 2014).

In any case, technical assistance is the main vehicle for overcoming smallholders' challenges, encouraging transfer of knowledge about new technologies and promoting the improvement of the marginal productivity of labor (Bernard \& Spielman, 2009). Thus, it is particularly relevant to identify whether extension services have a significant impact on the efficiency of cocoa farms. Knowledge about the effectiveness of extension programs can provide key insights for policymakers (Lampach et al., 2018). Moreover, farmers' technical efficiency and the effectiveness of public-funded extension programs and agrarian associations are not independent issues. Often, farmers' associations, such as cooperatives, provide professional advice to farmers that promotes an increase in a farmer's production and enhances their efficiency (Chang \& Wen, 2011). Additionally, farm efficiency can depend on a broad set of technological and socioeconomic factors (Silva et al., 2017).

A number of empirical studies conducted in Africa (the most important cocoa producer region producing $65 \%$ of world cocoa production) have estimated productivity and technical efficiency in cocoa production, especially in Ghana. For instance, Ofori-Bah \& Asafu-Adjaye (2011) and Onumah et al. (2013) emphasised the role of the extension of social contacts in explaining the differences in efficiency levels among cocoa farmers. Danso-Abbeam et al. (2012) and Besseah \& Kim (2014) also found some specific socioeconomic features that impacted on technical efficiency in Ghanaian cocoa-producing households. Also, a more recent study by Danso-Abbeam \& Baiyegunhi (2020) showed a high degree of complementarity among technical efficiency, welfare and extension services.

In Latin America, no prior research has estimated technical efficiency in cocoa production. Nonetheless, there are interesting studies in other crops. For instance, in Chile, Santos et al. (2006) described the positive effect on efficiency of a specific technology transference program in the case of potato. In Santander, Colombia, Trujillo \& Iglesias (2013) estimated that farmers with higher education levels and more experience reach higher levels of efficiency in pineapple. In Sinaloa, Mexico, Becerra-Pérez \& López-Reyes (2017) determined that membership of an agricultural association or group has a significant effect on farmers' productivity. Finally, Cavalleri Ferrari \& Braga (2021) found that veterinary technical assistance has reduced possible inefficiencies among the dairy producers in Uruguay. 


\section{Method}

The method used to determine the factors that affect technical efficiency dates back to the early 1990s (Kyei et al., 2011). The parametric technique to ascertain technical efficiency is based on stochastic frontier analysis (SFA), which was first proposed by Aigner et al. (1977), Meeusen, W., \& Van der Broeck (1977) and Färe \& Lovell (1978). The SFA econometric model is used to show the magnitude of the effect of the various factors on total output. In SFA, the farm is constrained to produce at or below the deterministic production frontier. This approach is preferred for efficiency studies in agriculture because of the inherent stochastic nature of agricultural systems (Onumah et al., 2013). One of the main advantages of the stochastic frontier model is the ability to predict how to create more value for farmers. Technically, this advantage is due to the model's ability to measure improvements in efficiencies that are able to create a pathway to optimisation (To-The \& Nguyen-Anh, 2020).

In addition to the random error in traditional regression models, the stochastic frontier production function involves an unobservable random variable that is associated with the technical inefficiency of production of individual farms (Battese \& Broca, 1997). A stochastic production frontier mode/ with output-oriented technical inefficiency can be specified as:

$\ln y_{i}=\ln y_{i}^{*}-u_{i}, \quad u_{i} \geq 0$,

$\ln y_{i}^{*}=f\left(\mathbf{x}_{i} ; \boldsymbol{\beta}\right)+v_{i}$,

where $y_{i}$ is a scalar of observed output, $\mathbf{x}_{i}$ is a $k \times 1$ vector of input variables, $\beta$ is a $k \times 1$ vector of the corresponding coefficient vector, $v_{i}$ is a zero-mean random error and $u_{i} \geq 0$ is the effect of production inefficiency. Basically, the SFA model includes a dependent parameter for explanation and optimisation as well as a set of explanatory variables that presumably have effects on this outcome (To-The \& Nguyen-Anh, 2020). Equation 2 defines the stochastic frontier of the production function. The frontier gives the fully efficient level of output (i.e., in the absence of inefficiency), and it is stochastic because of the presence of $v_{i}$.

Given that $u_{i} \geq 0$, the observed output ( $\ln y_{i}$ ) is bounded below the frontier, so it is sometimes convenient to write the model in the following form:

$\ln y_{i}=f\left(\mathbf{x}_{i} ; \boldsymbol{\beta}\right)+\varepsilon_{i}$

In this way, the error is compounded by the sum of a disturbance $v_{i}$ and another disturbance $u_{i}$, which represents inefficiency, with $u_{i}$ and $v_{i}$ being independent.

$\varepsilon_{i}=v_{i}-u_{i}$,

where $\varepsilon_{i}$ is the error term, which is often called the composed error term. This means that the SFA uses assumptions on the distribution of an unobserved productivity component to separate productivity from the deterministic part of the production function and the random error. Thus, this model allows the decomposition of the error term into random error $\left(v_{i}\right)$ and inefficiency error $\left(u_{i}\right)$ rather than attributing all errors to random effects (Battese \& Coelli, 1992; Bozoğlu \& Ceyhan, 2007).

According to Battese \& Coelli (1995), the error term $v_{i}$ is assumed to be identically, independently and normally distributed with mean zero and constant variance $\sigma_{v}^{2}$. This reflects measurement error, omitted variables and statistical noise (Wollni \& Brümmer, 2012). The error term, $u_{i}$, is also assumed to be distributed as a truncation of the normal distribution with mean $\mu$ and variance $\sigma_{u}^{2}$ (Battese \& Broca, 1997). 
Based on (1) and (2), a stochastic production frontier model with normal distribution of $v_{i}$ and a half-normal distribution of $u_{i}$ can be written as:

$$
\begin{aligned}
& \ln y_{i}=\ln y_{i}^{*}-u_{i} \\
& \ln y_{i}^{*}=\mathbf{x}_{i} \boldsymbol{\beta}+v_{i} \\
& u_{i} \sim N^{+}\left(0, \sigma_{u}^{2}\right) \\
& v_{i} \sim N\left(0, \sigma_{v}^{2}\right)
\end{aligned}
$$

where $\boldsymbol{\beta}, \sigma^{2}$ and $\sigma_{v}^{2}$ are the parameters to be estimated in the model (Kumbhakar \& Wang, 2015). Then, we can obtain $\lambda$, which represents the ratio between inefficiency and noise effects, and $\gamma$, which measures the ratio of frontier error variation and the composite error variation, as follows:

$\gamma=\sigma_{u}^{2} / \sigma^{2}$ and $\lambda=\sigma_{u} / \sigma_{v}$, where $\sigma^{2}=\sigma_{v}^{2}+\sigma_{u}^{2}$, so that $0 \leq \gamma \leq 1$.

The individual technical efficiency (TE) is predicted using the following equation (Battese \& Coelli, 1995):

$$
\mathrm{TE}_{i}=\exp \left(-u_{i}\right)
$$

where $\mathrm{TE}_{i}$ is defined as the ratio between the actual output and the potential output. The efficiency estimates enter the second-stage analysis to determine sources of technical efficiency among cocoa-producing households. The efficiency estimates fall in the interval between 0 and 1, which limits the dependent variable. A tobit model can be used to find the factors that explain the farms' efficiency through some exogenous variables (Tipi et al., 2009). The standard tobit model can be defined as follows:

$$
\begin{gathered}
T E_{i}^{*}=\mathbf{Z}_{i}^{T} \boldsymbol{\delta}+\varepsilon_{i}, i=1, \ldots, n, \\
T E_{i}=T E_{i}^{*} \text { if } T E_{i}^{*}<0 \\
T E_{i}=0, \text { otherwise }
\end{gathered}
$$

where $\varepsilon_{i}, \sim N\left(0, \sigma^{2}\right), \mathrm{TE}_{i}^{*}$ is a latent variable for the $i$ th farm and $\mathrm{TE}_{i}$ is the individual technical efficiency; $\mathbf{z}_{i}$ is a vector of exogenous variables associated with the technical efficiency effects of farm $i$; and $\delta$ is a vector of a set of unknown parameters connected with the independent variable to be estimated (Battese \& Broca, 1997; Onumah et al., 2013). The technical efficiency effects are modelled in terms of various explanatory variables, which can include functions of management characteristics and period of observation in both the frontier and the model for the inefficiency effects (Battese \& Coelli, 1995).

\section{Data and empirical model}

The research was conducted in the province of Tocache, in the San Martin region of Peru. According to the Peruvian Ministry of Agriculture (Ministerio de Desarrollo Agrario y Riego del Perú) (2021), in 2020, the San Martin region, which is the largest cocoa zona with approximately 2,775 cocoa farmers, produced 5,258.44 metric tons of cocoa from 4,409 ha of cultivated area (see Appendix 3). In the San Martin region, in Alto Huallaga (Huallaga), Tocache was identified on the one hand as Peru's "cocaine capital" (Van Dun, 2009) and on the other hand as one of the best cocoa-producing areas 
in the country (Laroche et al., 2012). The origin of the current Tochache social structure was in the 1960s with colonization by settlers of non-Indigenous background (Porro et al., 2015).

In the province of Tocache, there is a specific structure of cooperatives that is led by the "Central Cacao de Aroma" Cooperative (second-degree cooperative), followed by seven small cooperatives and associations located in different districts. These small cooperatives are responsible for the purchase and collection of their members' cocoa and supplying this output to the Central Cacao de Aroma. Primary data were collected at the study site in the six different districts where cooperatives are located (Polvora, Tocache, Cholón, Uchiza, Mishollo and Nuevo Progreso) between January and June 2015, with the support of authorities of Prodatu II-DEVIDA in the Tocache area.

Most previous studies on other crops in Latin America, such as the studies of Santos et al. (2006), Bozoğlu \& Ceyhan (2007), Trujillo \& Iglesias (2013), Danso-Abbeam et al. (2012), Onumah et al. (2013), Besseah \& Kim (2014) and To-The \& Nguyen-Anh (2020) among others, considered crosssectional data to determine the impact of training on technical efficiency. In our case, following a similar research design, farmers were approached randomly on cocoa farms and interviewed in person. We covered the whole area to make the sample representative. The total collected sample size was 379 cocoa farmers. The sample size for this study was calculated according to the following assumptions. With regard to the sample size of the cooperative members, we considered that the total population of the cooperatives in the six districts was 630 cocoa farmers. As 202 members were interviewed, 32\% of the total population was reached. As this selection was made assuming that it could be assimilated into a simple random sample, there was a sampling error of $7 \%$ with a $95 \%$ confidence interval. In the case of cocoa farmers who were not cooperative members (those who sell through intermediaries), the sample size was slightly lower (177) than that of cooperative members, as the number of farmers who sell through brokers was greater than the number of cooperative members (although not identified). Therefore, the level of error was somewhat higher than for the sample of cooperative members.

As a first step, a production frontier is estimated to obtain efficiency estimates, and as a second step, these estimates are regressed on a range of exogenous farm-specific variables (Wollni \& Brümmer, 2012). According to the generalised stochastic production function presented in Equation 3, the cocoa production equation was specified as a Cobb-Douglas functional form in order to fulfil the first objective of this investigation. The stochastic production function for cocoa farming was specified by:

$\ln y_{i}=\ln \beta_{0}+\beta_{1} \ln$ Land $_{i}+\beta_{2} \ln$ Capital $_{i}+\beta_{3} \ln$ Labour $_{i}+\beta_{4} \ln$ Input $_{i}+\varepsilon_{i}$,

where $y_{i}$ is the production output of a particular farm (the dependent variable), the individual variables identified as material, land, labor and capital (Table 1) are the independent variables specified in Cobb-Douglas functional form, and $\varepsilon_{i}$ is the composed error term (see Equation 4).

The independent socioeconomic variables used in the model are described in Tables 1 and 2. The topics on the questionnaire were based on several surveys previously conducted to assess the socio-demographic characteristics of households of age, income and household size (Tables 1 and 2). The selection of those variables is consistent with the preceding empirical literature (Bernard \& Spielman, 2009; Wollni \& Brümmer, 2012). 
Table 1. Summary statistics of the quantitative socioeconomic factors of the sample

\begin{tabular}{|c|c|c|c|c|}
\hline \multirow[t]{2}{*}{ Variable } & \multirow[t]{2}{*}{ Description } & $\begin{array}{c}\text { Total } \\
(n=379)\end{array}$ & $\begin{array}{c}\text { Coop } \\
\text { member } \\
(n=202)\end{array}$ & $\begin{array}{c}\text { Non-coop } \\
\text { member } \\
(n=177)\end{array}$ \\
\hline & & $\begin{array}{l}\text { Mean } \\
\text { (SD) }\end{array}$ & $\begin{array}{l}\text { Mean } \\
\text { (SD) }\end{array}$ & $\begin{array}{l}\text { Mean } \\
\text { (SD) }\end{array}$ \\
\hline Experience & $\begin{array}{l}\text { Experience in cocoa cultivation } \\
\text { (years) }\end{array}$ & $\begin{array}{l}7.0989 \\
(3.8330)\end{array}$ & $\begin{array}{l}7.8292 \\
(4.4119)\end{array}$ & $\begin{array}{l}6.2655 \\
(2.8310)\end{array}$ \\
\hline Yield & $\begin{array}{l}\text { Yield of a crop per unit area of land } \\
\text { (kg/ha) }\end{array}$ & $\begin{array}{l}0.8076 \\
(0.5114)\end{array}$ & $\begin{array}{c}0.9061 \\
(0.5676)\end{array}$ & $\begin{array}{l}0.6953 \\
(0.4122)\end{array}$ \\
\hline Diversification & Percent of other crops grown & $\begin{array}{c}0.2101 \\
(0.2361)\end{array}$ & $\begin{array}{l}0.2000 \\
(0.2379)\end{array}$ & $\begin{array}{l}0.2215 \\
(0.2341)\end{array}$ \\
\hline Production & $\begin{array}{l}\text { Total cocoa production of the farm } \\
(\mathrm{Tm})\end{array}$ & $\begin{array}{l}2.6166 \\
(2.0761)\end{array}$ & $\begin{array}{l}3.0297 \\
(2.5104)\end{array}$ & $\begin{array}{l}2.1452 \\
(1.2806)\end{array}$ \\
\hline Material & $\begin{array}{l}\text { Cost of standard fertilizers and } \\
\text { chemicals (soles*/ha) }\end{array}$ & $\begin{array}{c}1510.87 \\
(1112.99)\end{array}$ & $\begin{array}{c}1611.53 \\
(1055.39)\end{array}$ & $\begin{array}{l}1395.99 \\
(1167.72)\end{array}$ \\
\hline Land & $\begin{array}{l}\text { Number of hectares of cocoa land } \\
\text { (ha) }\end{array}$ & $\begin{array}{l}3.6922 \\
(1.9870)\end{array}$ & $\begin{array}{l}3.8186 \\
(2.1043)\end{array}$ & $\begin{array}{l}3.5480 \\
(1.8394)\end{array}$ \\
\hline Labour & $\begin{array}{l}\text { Ratio of power ( } 1 \text { if the ratio belongs } \\
\text { to a man; } 0.8 \text { to a woman; } 0.5 \text { to } \\
\text { children) }\end{array}$ & $\begin{array}{c}1.5979 \\
(0.8285)\end{array}$ & $\begin{array}{c}1.6728 \\
(0.8502)\end{array}$ & $\begin{array}{c}1.5124 \\
(0.7968)\end{array}$ \\
\hline Capital & $\begin{array}{l}\text { Investment in management/ } \\
\text { maintenance practices (soles*/year) }\end{array}$ & $\begin{array}{c}4448.77 \\
(4687.80)\end{array}$ & $\begin{array}{c}4921.76 \\
(3300.53)\end{array}$ & $\begin{array}{l}3908.98 \\
(5848.64)\end{array}$ \\
\hline Household & Number of household members & $\begin{array}{l}2.9208 \\
(1.3468) \\
\end{array}$ & $\begin{array}{c}3.3267 \\
(1.2587) \\
\end{array}$ & $\begin{array}{l}2.4576 \\
(1.2967) \\
\end{array}$ \\
\hline
\end{tabular}

*Sol is the Peruvian currency.

Table 2. Summary statistics of the qualitative socioeconomic factors of the sample

\begin{tabular}{|c|c|c|c|c|c|c|c|}
\hline \multirow{3}{*}{ Variable } & \multirow{3}{*}{ Description } & \multirow{2}{*}{\multicolumn{2}{|c|}{$\begin{array}{c}\text { Total } \\
(n=379) \\
\end{array}$}} & \multirow{2}{*}{\multicolumn{2}{|c|}{$\begin{array}{c}\text { Coop member } \\
(n=202)\end{array}$}} & \multirow{2}{*}{\multicolumn{2}{|c|}{$\begin{array}{c}\text { Non-coop member } \\
(n=177) \\
\end{array}$}} \\
\hline & & & & & & & \\
\hline & & Frequency & Percent & Frequency & Percent & Frequency & Percent \\
\hline Cooperative & $\begin{array}{l}1=\text { Member of } a \\
\text { cooperative } / 0=\text { Not } a \\
\text { member }\end{array}$ & 379 & $100.00 \%$ & 202 & $53.30 \%$ & 177 & $46.70 \%$ \\
\hline \multirow[t]{2}{*}{ Sex } & $1=$ Male & 344 & $90.80 \%$ & 182 & $90.10 \%$ & 162 & $91.50 \%$ \\
\hline & $0=$ Female & 35 & $9.20 \%$ & 20 & $9.90 \%$ & 15 & $8.50 \%$ \\
\hline \multirow[t]{2}{*}{ Coca } & 1 = Have cultivated coca & 264 & $69.70 \%$ & 156 & $77.20 \%$ & 108 & $61.00 \%$ \\
\hline & $0=$ Haven't cultivated coca & 115 & $30.30 \%$ & 46 & $22.80 \%$ & 69 & $39.00 \%$ \\
\hline \multirow[t]{2}{*}{ Machine } & $\begin{array}{l}1=\text { Have machinery and } \\
\text { equipment for cultivation }\end{array}$ & 105 & $27.70 \%$ & 53 & $26.20 \%$ & 52 & $29.40 \%$ \\
\hline & $\begin{array}{l}0=\text { No machinery and } \\
\text { equipment for cultivation }\end{array}$ & 274 & $72.30 \%$ & 149 & $73.80 \%$ & 125 & $70.60 \%$ \\
\hline \multirow[t]{4}{*}{$\begin{array}{l}\text { Technical } \\
\text { Assistance }\end{array}$} & $\begin{array}{l}0=\text { No technical assistance } \\
\text { in the year }\end{array}$ & 99 & $26.10 \%$ & 13 & $6.40 \%$ & 86 & $48.60 \%$ \\
\hline & $\begin{array}{l}1=\text { Technical assistance } \\
\text { once per year }\end{array}$ & 60 & $15.80 \%$ & 31 & $15.30 \%$ & 29 & $16.40 \%$ \\
\hline & $\begin{array}{l}2=\text { Technical assistance } \\
\text { twice per year }\end{array}$ & 57 & $15.00 \%$ & 34 & $16.80 \%$ & 23 & $13.00 \%$ \\
\hline & $\begin{array}{l}3=\text { Technical assistance } \\
\text { three or more times per } \\
\text { year }\end{array}$ & 163 & $43.00 \%$ & 124 & $61.40 \%$ & 39 & $22.00 \%$ \\
\hline
\end{tabular}




\section{Results and Discussion}

\subsection{Results of the efficiency estimation}

The productivity estimates (coefficients) of the independent variables were explained in terms of output elasticities. In the case of this Cobb-Douglas form, production elasticities can be directly inferred from the estimated coefficients (Wollni \& Brümmer, 2012). Table 3 shows that all of the explanatory variables from equation (12) exhibited a significant and positive relationship with cocoa output for the total sample. The observed signs of the explanatory variables were consistent with the a priori expectation supported by previous results (DansoAbbeam et al., 2012; Wollni \& Brümmer, 2012).

Table 3. Stochastic frontier analysis of cocoa production through both marketing channels

\begin{tabular}{|c|c|c|c|c|c|}
\hline \multirow{2}{*}{ Variable } & \multirow{2}{*}{$\boldsymbol{\beta}$ (Std. Error) $^{\ddagger}$} & \multirow{2}{*}{$\mathbf{z}$} & \multirow{2}{*}{ p-value } & \multicolumn{2}{|c|}{$95 \%$ confidence intervals } \\
\hline & & & & Lower & Upper \\
\hline Intercept & $-4.38(0.42) * \star \star$ & -10.34 & $<0.01$ & -5.2162 & -3.5532 \\
\hline Ln (Capital) & $0.44(0.05) * * *$ & 9.44 & $<0.01$ & 0.3473 & 0.5293 \\
\hline Ln (Labour) & $0.21(0.06) * \star \star$ & 3.63 & $<0.01$ & 0.0966 & 0.3238 \\
\hline Ln (Material) & $0.24(0.04) * * *$ & 6.51 & $<0.01$ & 0.1659 & 0.3087 \\
\hline Ln (Land) & $0.25(0.06) * \star \star$ & 4.21 & $<0.01$ & 0.1319 & 0.3620 \\
\hline$\Lambda$ & & & 1.5564 & & \\
\hline$\sigma_{u}$ & & & 0.6441 & & \\
\hline$\sigma_{v}$ & & & 0.4138 & & \\
\hline Log likelihood & & & -319.66 & & \\
\hline Wald chi2(4) & & & 317.80 & & \\
\hline Prob>chi2 & & & 0.00 & & \\
\hline
\end{tabular}

Farm level information on efficiency and productivity is generally unsatisfactory (Bozoğlu \& Ceyhan, 2007). A best management practice is said to be any method or practice that is technically sound and that when utilized in crop production prevents or reduces the common problems related to general agricultural production and yield results (Adom, 2019). Many tropical and subtropical crops such as cocoa display a tendency to produce declining yields over time (Florkowski \& Sarmiento, 2005). A proxy variable to measure the capital was management or crop maintenance practices, since cocoa is a perennial crop. These management practices include the use of cover crops, crop rotation, intercropping, agroforestry, soil testing record keeping, proper water management, pesticide and/or fertilizer management and tillage systems, amongst others (Adom, 2019). Paying close attention to these key issues in crop management can maximize yield (Adom, 2019). Outcomes show that if capital, as measured by investment in maintenance, rises by $1 \%$, cocoa production increases by $0.44 \%$. With regard to labor, family farmers often also hire farmworkers, particularly for harvesting, but also for general maintenance tasks (Curry et al., 2015). The high relevance of labor can be explained by the fact that cocoa is a labor-intensive crop that requires activities such as weed removal, tree pruning, shading to preserve biodiversity and to control insect infestation, and integrated pest management (Wollni \& Brümmer, 2012).

Most studies have used the term 'labor' to designate working hours irrespective of gender (Bozoğlu \& Ceyhan, 2007). Nonetheless, a power proportion of males, females and children of 1:0.8:0.5 (Gangil \& Pandey, 2003) was used, multiplying them by the number of males, females 
and children who work on the farm. Thus, labor positively correlated with increased yields. Consistent with economic theory, the production elasticity with respect to labor was positive and statistically significant at the $1 \%$ level. This means that production will grow by $0.21 \%$ if the labor work power increases by $1 \%$, keeping the rest constant. From these results, it can be identified that the two most important components affecting cocoa production are labor and investment in maintenance by farmers for both types of marketing channels. Additionally, the use of fertilizers has a positive effect on yields. In this case, an increase of $1 \%$ in the investment in chemical or conventional fertilizers leads to an increment in the quantity of cocoa produced of $0.24 \%$. These findings are consistent with others reported in the academic literature about this topic. Kyei et al. (2011) suggested that the size of farmland and the quantity of fertilizer and pesticide influence farm output in Ghana. These outcomes also apply to Peruvian cocoa production. Finally, the farm size (land) is an important factor in the explanation of production. An increase of $1 \%$ in the number of cocoa hectares generates $0.25 \%$ growth in production.

In order to check the relevance of the stochastic frontier model, we calculated the total variance of the error term $\left(\sigma^{2}\right)$. By applying the variance parameters $\sigma^{2}$ and $\gamma$ defined in Section 3, according to the standard deviations presented in Table 3, the variance proportion of the technical efficiency component $(\gamma)$ could be determined. Estimated gamma $(\gamma)$ was significant for the total sample with 0.71 (Table 4), which is a figure that is closer to 1 than 0. All farmers together produced on average $71 \%$ of potential output given the level of factors available. Thus, the deviation from the frontier was attributable to $29 \%$ of technical inefficiency. This fact indicates that producers can still improve results by using more efficient production practices. Related to cocoa production, Ofori-Bah \& Asafu-Adjaye (2011) reported that the technical efficiency scores for multiple cropped cocoa farms had an average value of 0.86 , while for mono-crop cocoa farms it was 0.47 on average. Onumah et al. (2013) found that the mean technical efficiency of the cocoa producers in the Eastern Ghana area was $85 \%$, while the study of Danso-Abbeam et al. (2012) in Western Ghana found a mean of $49 \%$. Additionally, the ratio between inefficiency and noise effects, represented by lambda $(\lambda)$, was also significant at 1.56 (Table 4), which indicates that the inefficiency effects in the model are much higher than the corresponding idiosyncratic noise effects. The null hypothesis that the variance of the inefficiency error term is zero was also rejected at the $1 \%$ significance level, implying high variation in inefficiency error (Besseah \& Kim, 2014). Table 4 additionally displays the Wald chisquare values, showing the overall significance of the estimated model in the Cobb-Douglas functions. Thus, an opportunity to increase production in the Peruvian cocoa sector exists by applying better farming practices without increasing any inputs (Besseah \& Kim, 2014).

Table 4. Parameterization of stochastic frontier analysis

\begin{tabular}{cccccccc} 
& $\lambda$ & $\sigma^{2}$ & $\sigma_{v}^{2}$ & $\gamma$ & Mean efficiency & Log likelihood & Wald chi $^{2}$ \\
Total & 1.56 & 0.59 & 0.17 & 0.71 & 0.6404 & -319.66 & $317.8^{* \star *}$ \\
\hline
\end{tabular}

Table 5 provides the results of the efficiency model (Equation 9). It is worth noting that a negative sign of a coefficient means that the predicted effect on efficiency is negative (Wollni \& Brümmer, 2012). When estimating a production frontier, the underlying assumption is that all farmers in the sample (cooperative members or sellers via intermediaries) have access to the same production technology. 
Table 5. Determinants of technical efficiency

\begin{tabular}{lccccc}
\multicolumn{1}{c}{ Variable } & B & SE & z-value & p-value & Sig. \\
Intercept & 0.5473 & 0.030 & 18.02 & $<0.01$ & $* * *$ \\
Sex1 & 0.0542 & 0.024 & 2.31 & 0.0211 & $* *$ \\
Diversification & -0.0746 & 0.029 & -2.54 & 0.0112 & $* *$ \\
Experience & 0.0102 & 0.002 & 5.56 & $<0.01$ & $* * *$ \\
Cooperative1 & -0.0132 & 0.017 & -0.80 & 0.4267 & N.S. \\
Machine1 & -0.0100 & 0.016 & -0.64 & 0.5194 & N.S. \\
Household & -0.0072 & 0.005 & -1.34 & 0.1803 & N.S. \\
Technicalassist1 & 0.0180 & 0.023 & 0.80 & 0.4242 & N.S. \\
Technicalassist2 & 0.0190 & 0.023 & 0.82 & 0.4138 & N.S. \\
Technicalassist3 & 0.0361 & 0.020 & 1.83 & 0.0670 & $*$ \\
Coca1 & -0.0047 & 0.015 & -0.30 & 0.7619 & N.S. \\
Log(scale) & -2.0318 & 0.036 & -55.94 & $<0.01$ & $* * *$ \\
Log-likelihood & & 232.3 & & & $* *$ \\
Wald-statistic & & 56.570 & & &
\end{tabular}

* $p<0.10, * * p<0.05, * * * p<0.01$

In our study, the extension variable is defined as the number of times farmers attend training classes per year. Technical assistance classes involve seedling production, harvesting method and crop care (To-The \& Nguyen-Anh, 2020). Having fewer than two technical assistance sessions per year did not have a significant effect on efficiency. In their study in Ghana, Ofori-Bah \& Asafu-Adjaye (2011) reported that their measure of extension contact was not significant. They concluded that the quality of extension services has a limited impact on cocoa productivity in developing countries. In spite of this, our study showed that having three or more technical assistance sessions per year has a marginal significant effect on the efficiency of cocoa production $(p<0.10)$. The results of Onumah et al. (2013) also demonstrated that farmers who had increased frequency of extension visits produced less inefficiency compared to farmers who had few contacts with extension agents. They said that effective extension visits and supervision will go a long way to improving cocoa farmers' production efficiency. A possible reason that certain farmers have a higher probability of receiving more extension services is wealth. Danso-Abbeam \& Baiyegunhi (2020) mentioned that wealthy households have better access to information and other services such as extension services than the poorer households.

In other crops, Santos et al. (2006), for instance, described that a determined technology transference program had a direct and significant effect on the technical efficiency in Chilean potato producers. Bozoğlu and Ceyhan (2007) also reported that the information score as a variable of frequency of contact with Turkish extension programs was significant in vegetables. In addition, our outcomes are in line with those of the Cavalleri Ferrari \& Braga (2021) study. They mentioned that veterinary care was one of the determinants that most contributed to reducing inefficiency in their study on Uruguayan dairy farmers. Thus, as it appears that farmers with a high information score are more efficient (Bozoğlu \& Ceyhan, 2007), it is important for farmers to get more technical assistance, which can be either paid assistance or assistance freely provided by public agencies (Ministry of Agriculture) or NGOs.

In this study, we also used a binomial variable named cooperative to determine whether there is a significant effect of cooperative membership on the technical efficiency of cocoa farmers' production. The selection of this variable was in line with Gutiérrez (2014), who mentioned that the selection of agricultural cooperatives as instruments for rural smallholders' development allows individual farmers to overcome constraints that prevent them from raising their living standards. Chang \& Wen 
(2011) also showed that cooperative activities improved the technical efficiency of rice production in the local area in which each farm was located. Furthermore, Becerra-Pérez \& López-Reyes (2017) showed that Mexican corn farmers that are part of an organization were more likely to be technically efficient than those who did not belong to any organization. Even though these studies were not related to cocoa, they show the impact of organization membership on technical assistance.

Nonetheless, we found no significant effect of cooperative membership on the technical efficiency of cocoa farmers $(p>0.10)$; therefore, cooperative membership did not seem to be a determinant of productivity in our study. However, the quality control and volume required for cocoa compared to the other crops studied previously differ greatly due to the nature of each product. More empirical research on cocoa production is required in order to better support explanation of the case of cocoa production in Peru. Future research just with cooperative members should be conducted in order to capture the impact of membership on cocoa technical efficiency. Another point to note is that although the outcome of cocoa cooperative membership was not significant, the sign of the coefficient was negative, which was contrary to what was expected. This counterintuitive result can be explained by differences in quality control procedures, which are translated into higher volumes produced by the farmers who sell through intermediaries. Small farmers do not have adequate knowledge about downstream markets due to lack of standardization and quality control, which results in them selling their produce to informal retailers or intermediaries at lower prices (Gutiérrez, 2014). It is said that cooperative membership is associated particularly with the adoption of quality standards in harvesting (Ma et al., 2017) and post-harvesting activities, as cocoa involves particularly demanding processing in terms of drying and fermentation. As a result, there is a larger quantity but poorer quality of cocoa supplied by farmers who sell through intermediaries.

Other indicators were found to be significant determinants of technical efficiency. For instance, farming experience (years of experience in cocoa farming) had a significant effect $(p<0.01)$, as more experienced farmers had greater willingness to run the risk involved in adoption of innovations. Our results are in line with those of Danso-Abbeam et al. (2012), Onumah et al. (2013) and Besseah \& Kim (2014), who also found that age and experience had a positive effect on technical efficiency of cocoa farmers. Additionally, in other crops, Bozoğlu \& Ceyhan (2007) reported that more years of experience in vegetable farming led to better managerial skills. Santos et al. (2006) and Trujillo \& Iglesias (2013) also showed that experience has a positive impact on technical efficiency in Chilean potatoes and Colombian pineapple, respectively. Moreover, the outcomes indicated that male farmers are an important determinant of technical efficiency $(p<0.05)$. Since cocoa is produced in the Peruvian jungle predominantly by family farms, the farm labor force consists mainly of the male household members. The owner of the farm oversees day-to-day operations and hires part-time labor to help on the farm. Onumah et al.'s (2013) study had the same results, and the authors mentioned that male farmers are less inefficient compared to their female counterparts. Danso-Abbeam \& Baiyegunhi (2020) said that this feature can be partly attributed to the tedious nature of cocoa farming which, seems more suitable for male farmers than their counterparts. Additionally, we observed that less diversification increased the efficiency of cocoa growing $(p<0.05)$. This result differs from that reported by Besseah \& Kim (2014), who found a positive influence of diversification on technical efficiency at the $5 \%$ level. In contrast, our results showed that if farmers only dedicate and invest in resources allocated to cocoa as a monoculture, they gain more expertise in crop management and thus are more efficient. Ofori-Bah \& Asafu-Adjaye (2011) also reported in their Ghanaian cocoa study that their gender and diversity index variables had the expected sign and were both not statistically significant. 


\section{Conclusions}

This study demonstrated several issues related to the productivity of cocoa in the Peruvian Amazon. First, it demonstrated that there has been a considerable increase in the production of cocoa in the Peruvian Amazon, which is mainly explained by the factors of labor, capital, cocoa lands and the use of fertilizers $(p<0.01)$. In our study, the deviation from the frontier was attributable to $29 \%$ technical inefficiency. This situation indicates there is an opportunity to increase production in the Peruvian cocoa sector by applying better farming practices with the current inputs. Second, this study demonstrated that participating in three or more technical assistance sessions per year has a significant effect on the efficiency of cocoa production $(p<0.10)$. This result has implications not only for evaluating farm productivity but also for designing effective agricultural extension programs to increase the efficiency of using available resources. Agricultural policies can rely on extension services to improve farm productivity by conveying information from researchers to farmers, for instance on the use of pesticides with environmentally friendly components. On the other hand, in our sample, cooperative membership did not have a significant impact on the technical efficiency of cocoa production $(p>0.10)$. A possible explanation is that the activities of cooperatives have been more focused on improvement of the post-harvesting phases (drying and fermentation), which are more related to cocoa quality than volume.

Some implications can be extracted from the literature review and results of this study. In order to help cocoa farmers to boost their current levels of efficiency, the government should offer extension services that are organized by educators and encompass a wide array of communication, technology and technical and managerial skill activities. In particular, an increase in relevant alternatives provided by regional and local governments for the development of technical productive skills through participatory community programs is needed. A well-directed extension service program to farmers according to their needs, the region they belong and also the crops they are working on should be designed. Greater investments should also be made in the generation and transfer of innovation and the co-financing of community-driven projects to produce local inputs. Additionally, farmers' access to information should be enhanced by the provision of better extension services and farmer training programs. With information on the work of extension agents, researchers and private advisors, farmers can improve their technical efficiency, which will enable them to grow greater quantities of better quality cocoa.

It is necessary to mention that this study experienced limitations. First, a larger sample size would probably show more variation in output and also in the level of technical efficiency. Second, restricting the study to a very specific region had some advantages, as it made it possible to isolate the phenomena of interest for close examination. Nonetheless, this study is subject to constraints inherent to this type of research. Third, the article only assessed the quantity of technical assistance received by farmers and did not assess the quality. This aspect should be studied in future works. Fourth, longitudinal research is recommended to observe whether the evolution of variables over an extended period of time could help to improve the Peruvian cocoa sector. Further research should also be conducted on cooperative membership and credit access, as these variables make a significant contribution not only to the productivity of the cocoa fields in Tocache but also to the wellbeing of Peruvian cocoa farmers as a whole.

\section{References}

Admassie, A., \& Matambalya, F. (2014). Technical efficiency of small-and medium-scale enterprises: evidence from a survey of enterprises in Tanzania. Eastern Africa Social Science Research Review, 18(2), 1-29. 
Adom, D. (2019). Good management practices for agricultural crops: a mini review. Scientia Agrícola, 3(6), 8-11.

Aigner, D., Lovell, K., \& Schmidt, P. (1977). Formulation and estimation of stochastic frontier production function models. Journal of Econometrics, 6(1), 21-37.

Barham, E., \& Sylvander, B. (2011). Labels of origin for food: local development, global recognition. Wallingford, Reino Unido: CABI.

Battese, G. E., \& Broca, S. S. (1997). Functional forms of stochastic frontier production functions and models for technical inefficiency effects: a comparative study for wheat farmers in Pakistan. Journal of Productivity Analysis, 8, 395-414.

Battese, G. E., \& Coelli, T. J. (1992). Frontier production functions, technical efficiency and panel data: with application to paddy farmers in India. Journal of Productivity Analysis, 3, 153-169.

Battese, G. E., \& Coelli, T. J. (1995). A model for technical inefficiency effects in a stochastic frontier production function for panel data. Empirical Economics, 20, 325-332.

Becerra-Pérez, L., \& López-Reyes, L. (2017). Technical efficiency of corn production in Sinaloa, Mexico (Paper presentation). In 20th Annual Conference on Global Economic Analysis. West Lafayette, USA: Purdue University. Retrieved in 2021, June 15, from https://www.gtap. agecon.purdue.edu/resources/res_display.asp?RecordID=5264

Bernard, T., \& Spielman, D. J. (2009). Reaching the rural poor through rural producer organizations? A study of agricultural marketing cooperatives in Ethiopia. Food Policy, 34(1), 60-69.

Besseah, F. A., \& Kim, S. (2014). Technical efficiency of cocoa farmers in Ghana. Journal of Rural Development, 37(2), 1-24.

Bozoğlu, M., \& Ceyhan, V. (2007). Measuring the technical efficiency and exploring the inefficiency determinants of vegetables farms in Samsun province, Turkey. Agricultural Systems, 94(3), 649-656.

Cavalleri Ferrari, M., \& Braga, M. J. (2021). A eficiência técnica dos produtores leiteiros no Uruguai. Revista de Economia e Sociologia Rural, 59(2), e221319. http://dx.doi.org/10.1590/18069479.2021.221319

Chang, H.-H., \& Wen, F.-I. (2011). Off-farm work, technical efficiency, and rice production risk in Taiwan. Agricultural Economics, 42(2), 269-278.

Cidell, J. L., \& Alberts, H. C. (2006). Constructing quality: the multinational histories of chocolate. Geoforum, 37(6), 999-1007.

Comisión Nacional para el Desarrollo y Vida sin Drogas - DEVIDA. (2020). Monitoreo de superficie cultivada con arbusto de hoja de coca en producción, Perú 2019 (Reporte de superficie cultivada, Nº02-2020). Perú: Comisión Nacional para el Desarrollo y Vida sin Drogas.

Coq-Huelva, D., Torres-Navarrete, B., \& Bueno-Suárez, C. (2018). Indigenous worldviews and Western conventions: Sumak Kawsay and cocoa production in Ecuadorian Amazonia. Agriculture and Human Values, 35(1), 163-179.

Curry, G. N., Koczberski, G., Lummani, J., Nailina, T., Peter, E., McNally, G., \& Kuaimba, O. (2015). A bridge too far? The influence of socio-cultural values on the adaptation responses of smallholders to a devastating pest outbreak in cocoa. Global Environmental Change, 35, 1-11.

Danso-Abbeam, G., \& Baiyegunhi, L. J. S. (2020). Do farm-level technical efficiency and welfare complement each other? Insight from Ghana's cocoa industry. Economic Structures, 9, 23. https://doi.org/10.1186/s40008-020-00200-w 
Danso-Abbeam, G., Aidoo, R., Agyemang, K. O., \& Ohene-Yankyera, K. (2012). Technical efficiency in Ghana's cocoa industry: Evidence form Bibiani-Anhwiaso-Bekwai District. Journal of Development and Agricultural Economics, 4(10), 287-294.

Färe, R., \& Lovell, C. K. (1978). Measuring the technical efficiency of production. Journal of Economic Theory, 19(1), 150-162.

Florkowski, W. J., \& Sarmiento, C. (2005). The examination of pecan price differences using spatial correlation estimation. Applied Economics, 37(3), 271-278.

Gangil, S., \& Pandey, K. C. (2003). Energy expenditure for post harvest operations in village Barkheda Nathu in Bhopal district. In International Seminar on Downsizing Technology for Rural Development (pp. 95-99). India: Regional Research Laboratory.

Gibbon, P., Ponte, S., \& Lazaro, E. (2010). Global agro-food trade and standards: challenges for Africa. London: Palgrave Macmillan.

Gutiérrez, J. D. (2014). Smallholders' agricultural cooperatives in Colombia: vehicles for rural development? Desarrollo y Sociedad, 73, 219-271.

Kumbhakar, S. C., \& Wang, H.-J. (2015). Estimation of technical inefficiency in production frontier models using cross-sectional data. In S. C. Ray, S. C. Kumbhakar, \& P. Dua (Eds.), Benchmarking for performance evaluation: a production frontier approach (pp. 1-73). USA: Springer.

Kyei, L., Foli, G., \& Ankoh, J. (2011). Analysis of factors affecting the technical efficiency of cocoa farmers in the Offinso district - Ashanti region, Ghana. American Journal of Social and Management Sciences, 2(2), 208-216.

Lampach, N., Nguyen-Van, P., \& To The, N. (2018). The effect of agricultural extension programs on technical efficiency of crop farms in low and middle-income countries (pp. 1-52). SSRN. https://doi.org/10.2139/ssrn.3208034.

Laroche, K., Jiménez, R., \& Nelson, V. (2012). Assessing the impact of fairtrade for Peruvian coca farmers. UK: Natural Resources Institute. https://doi.org/10.13140/2.1.1107.7443.

Ma, W., Abdulai, A. \& Goetz, R. (2017). Agricultural cooperatives and investment in organic soil amendments and chemical fertilizer in China. American Journal of Agricultural Economics, 100(2): 502-520.

Martin, S., Rieple, A., Chang, J., Boniface, B., \& Ahmed, A. (2015). Small farmers and sustainability: Institutional barriers to investment and innovation in the Malaysian palm oil industry in Sabah. Journal of Rural Studies, 40, 46-58.

Meeusen, W., \& Van der Broeck, J. (1977). Efficiency estimation from Cobb-Douglas production functions with composed error. International Economic Review, 18, 435-444.

Melo, C. J., \& Hollander, G. M. (2013). Unsustainable development: Alternative food networks and the Ecuadorian Federation of Cocoa Producers, 1995-2010. Journal of Rural Studies, 32, 251-263.

Mojo, D., Fischer, C., \& Degefa, T. (2017). The determinants and economic impacts of membership in coffee farmer cooperatives: recent evidence from rural Ethiopia. Journal of Rural Studies, 50, 84-94.

Ofori-Bah, A., \& Asafu-Adjaye, J. (2011). Scope economies and technical efficiency of cocoa agroforesty systems in Ghana. Ecological Economics, 70(8), 1508-1518.

Onumah, J. A., Al-Hassan, R. M., \& Onumah, E. E. (2013). Productivity and technical efficiency of cocoa production in eastern Ghana. Journal of Economics and Sustainable Development, $4(4), 106-117$. 
Organización de las Naciones Unidas para la Agricultura y la Alimentación - FAOSTAT. (2021). Datos. Retrieved in 2021, June 15, from http://www.fao.org/faostat/es/\#data

Perú. Ministerio de Desarrollo Agrario y Riego. (2021). Estadística agropecuaria. Retrieved in 2021, June 15, from https://siea.midagri.gob.pe/portal/siea_bi/index.html

Ponte, S. (2009). Governing through quality: Conventions and supply relations in the value chain for South African wine. Sociologia Ruralis, 49(3), 236-257.

Porro, R., Lopez-Feldman, A., \& Vela-Alvarado, J. W. (2015). Forest use and agriculture in Ucayali, Peru: Livelihood strategies, poverty and wealth in an Amazon frontier. Forest Policy and Economics, 51, 47-56.

Santos, J., Foster, W., Ortega, J., \& Ramirez, E. (2006). Study of the technical efficiency of potato producers in Chile: the role of INDAP's Technology Transference Program (PTT). Economía Agraria, 10, 119-132.

Schweisguth, M. A. (2015). Evaluating the effects of certification on smallholders' net incomes, with a focus on cacao farmers in cooperatives in Cote d'Ivoire (Master's thesis]. University of California, California.

Silva, J. V., Reidsma, P., Laborte, A. G., \& Van Ittersum, M. K. (2017). Explaining rice yields and yield gaps in Central Luzon, Philippines: an application of stochastic frontier analysis and crop modelling. European Journal of Agronomy, 82, 223-241.

Tipi, T., Yildiz, N., Nargeleçekenler, M., \& Çetin, B. (2009). Measuring the technical efficiency and determinants of efficiency of rice (Oryza sativa) farms in Marmara region, Turkey. New Zealand Journal of Crop and Horticultural Science, 37(2), 121-129.

Torres, N. A., \& Davalos, E. (2019). Heterogeneous effects of agricultural technical assistance in Colombia (Master's thesis). University EAFIT, Colombia.

To-The, N., \& Nguyen-Anh, T. (2020). Impact of government intervention to maize efficiency at farmer's level across time: a robust evidence in Northern Vietnam. Environment, Development and Sustainability, http://dx.doi.org/10.1007/s10668-020-00662-9

Trujillo, J. C., \& Iglesias, W. J. (2013). Measurement of the technical efficiency of small pineapple farmers in Santander, Colombia: a stochastic frontier approach. Revista de Economia e Sociologia Rural-RESR, 51(1), 49-62.

Van Dun, M. (2009). Cocaleros: violence, drugs and social mobilization in the post-conflict Upper Huallaga Valley, Peru. Rozenberg Publishers.

Wollni, M., \& Brümmer, B. (2012). Productive efficiency of specialty and conventional coffee farmers in Costa Rica: Accounting for technological heterogeneity and self-selection. Food Policy, 37(1), 67-76.

World Cocoa Foundation. (2014). Cocoa market update. Retrieved in 2021, June 15, from http:// www.worldcocoafoundation.org/wp-content/uploads/Cocoa-Market-Update-as-of-4-1-2014.pdf 
Appendix 1 - Cultivated area in hectares with coca leaf bush in production at the Peruvian national level and Huallaga area (2013-2019)

Coca leaf bush level (2013-2019)

$$
\multimap \text { Peru } \longrightarrow \text { Huallaga }
$$

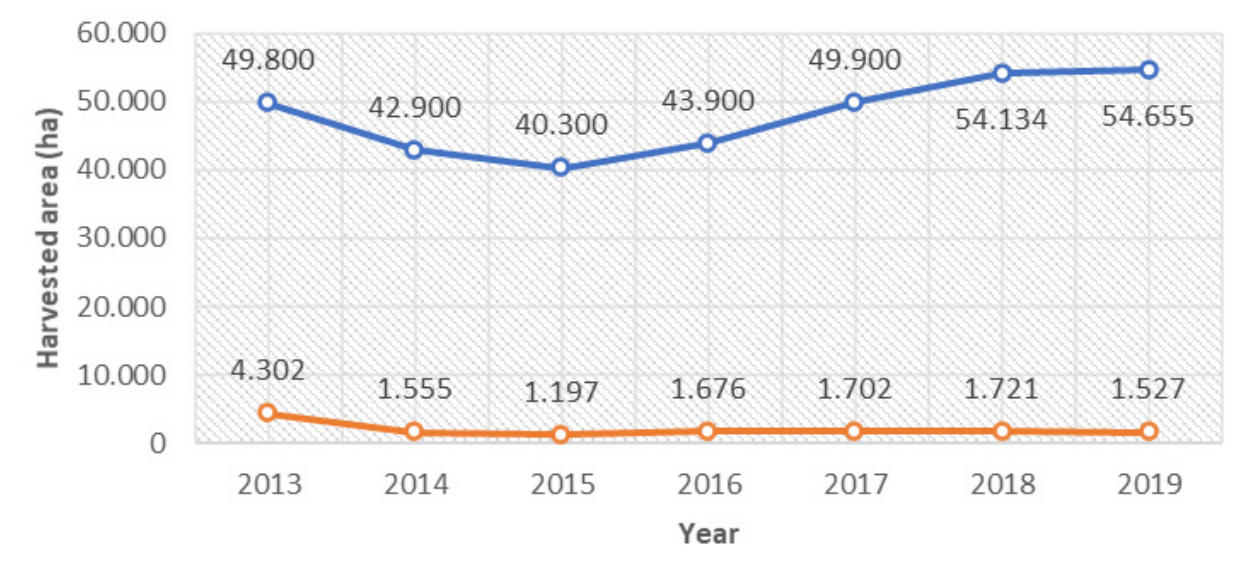

Source: Devida (Comisión Nacional para el Desarrollo y Vida sin Drogas, 2020) 
Appendix 2 - World, South America and Peruvian cocoa yields (2013-2019)

\begin{tabular}{cccc} 
Years & World (kg/ha) & South America (kg/ha) & Perú (kg/ha) \\
2013 & 246,072 & 32,342 & 7,288 \\
2014 & 267,676 & 33,701 & 7,657 \\
2015 & 265,625 & 34,375 & 7,692 \\
2016 & 274,205 & 34,222 & 8,594 \\
2017 & 290,809 & 39,439 & 8,270 \\
2018 & 297,624 & 40,643 & 8,395 \\
2019 & 299,650 & 42,950 & 10,426 \\
\hline
\end{tabular}

Source: FAOSTAT (Organización de las Naciones Unidas para la Agricultura y la Alimentación, 2021) 
Appendix 3 - Cocoa production data in San Martín province (Peru) (2015-2020)

\begin{tabular}{ccccc} 
Years & $\begin{array}{c}\text { Production } \\
\text { quantity (t) }\end{array}$ & $\begin{array}{c}\text { Harvested area } \\
\text { (ha) }\end{array}$ & $\begin{array}{c}\text { Yield } \\
\text { (t/ha) }\end{array}$ & $\begin{array}{c}\text { Price field } \\
\text { (Nuevos soles / kg) }\end{array}$ \\
\hline 2015 & $3,481.5$ & $3,874.5$ & 0.90 & 7.35 \\
2016 & $3,977.1$ & $4,261.0$ & 0.93 & 8.06 \\
2017 & $4,285.7$ & $4,457.0$ & 0.96 & 5.44 \\
2018 & $4,207.0$ & $4,597.5$ & 0.92 & 5.78 \\
2019 & $5,389.3$ & $4,356.0$ & 1.24 & 6.25 \\
2020 & $5,258.4$ & $4,409.0$ & 1.19 & 7.52 \\
\hline
\end{tabular}

Source: Peruvian Ministry of Agriculture (Perú, 2021) 